Article

\title{
Reactive Black 5 Degradation on Manganese Oxides Supported on Sodium Hydroxide Modified Graphene Oxide
}

\author{
Hayarpi Saroyan, Dimitra Ntagiou, Kyriazis Rekos and Eleni Deliyanni *D \\ Laboratory of Chemical and Environmental Technology, Department of Chemistry, Aristotle University of \\ Thessaloniki, 54124 Thessaloniki, Greece; haysarsam@yahoo.com (H.S.); dntagiou@chem.auth.gr (D.N.); \\ rekoskyriazis@yahoo.gr (K.R.) \\ * Correspondence: lenadj@chem.auth.gr
}

Received: 10 March 2019; Accepted: 17 May 2019; Published: 27 May 2019

\begin{abstract}
Sodium hydroxide-modified graphene oxide was used as manganese oxides support for the preparation of nanocomposites via a one-pot preparation route for the degradation of Reactive Black 5. The nanocomposites were characterized for their structure by X-ray diffraction, for their textural properties by Nitrogen adsorption, and for their surface chemistry by Fourier transform infrared spectroscopy, potentiometric titration, and thermal analysis measurements. The nanocomposites prepared showed to possess high activity for the degradation/oxidation of Reactive Black 5 at ambient conditions, without light irradiation, which was higher than that of the precursors manganese oxides and can be attributed to the synergistic effect of the manganese oxides and the modified graphene oxide.
\end{abstract}

Keywords: modified graphene oxide; Reactive Black 5; degradation; manganese oxide

\section{Introduction}

The textile industries effluents contain dyes, provoking several effects on ecosystems and effects on human health [1-7]. Most industries use synthetic azo dyes with one or more azoic groups $(-\mathrm{N}=\mathrm{N}-)$ that may form aromatic amines causing mutagenic and carcinogenic effects on aquatic organisms [8-14].

Many research papers have focused on the removal methods of azo dyes in order to decrease their effect on environment and human health. These techniques could be classified in biological (biodegradation, biosorption, bioaccumulation, applying bacteria, or algae) [15-18], chemical (ozonation, advanced oxidation processes (AOPs), electrochemical degradation, photocatalysis) [19-22] and physical methods (adsorption, ion exchange) [23-25], depending on the type of process. Adsorption is considered to be quite attractive in terms of effectiveness and ultimate removal, while catalytic oxidation in terms of cost and of a high degree of dye elimination [26-28].

Recently, significant research efforts have been focused on the environmental application of manganese oxides $\mathrm{MnO}_{\mathrm{x}}(\mathrm{x}=1,2,4 / 3)$, because of their low cost, abundance, environmental friendliness, and high adsorption capacity $[29,30]$. In particular, manganese oxide/nanomaterials demonstrated oxidative and catalytic activity for the degradation of dyes and organic compounds from aqueous waste [31,32]. Furthermore, manganese oxides are powerful oxidizing/catalytic agents [33].

Carbonaceous materials like activated carbon and graphene oxide have been used for dye removal due to the advantage of their selective adsorption capacity through a strong $\pi-\pi$ interaction of the benzene rings [34-36]. Recently, activated carbon and graphene oxide were used as support for manganese oxides for the synthesis of nanocomposites for a dye degradation $[37,38]$ while sodium hydroxide modified graphene oxide was used as support of manganese oxides for the 
preparation of novel nanocatalysts applied to the catalytic degradation of bisphenol A $[39,40]$. The novel nanocomposites presented a sufficient performance of bisphenol A degradation attributed to a synergetic effect of adsorption onto the carbonaceous support and the oxidation onto the manganese oxides' surface.

In the current study, sodium hydroxide modified graphene oxide was used as support of manganese oxides $\left(\mathrm{MnO}_{2}\right.$ and $\left.\mathrm{Mn}_{3} \mathrm{O}_{4}\right)$ and were tested for the degradation of the azo dye Reactive Black 5. The nanocomposites showed to possess high activity for the degradation/oxidation of the dye at ambient conditions, without light irradiation, which was higher than that of the precursors' manganese oxides. The increased degradation can be attributed to the synergistic effect of the adsorption onto modified graphene oxide and oxidation onto manganese oxides. The presence of radicals further increased the dye degradation.

\section{Experimental}

\subsection{Materials and Reagents}

Reagents of graphite powder, potassium permanganate $\left(\mathrm{KMnO}_{4}\right)$, sulfuric acid $\left(\mathrm{H}_{2} \mathrm{SO}_{4}\right)$ as well as sodium hydroxide $(\mathrm{NaOH})$ and manganese sulphate $\left(\mathrm{MnSO}_{4} \cdot 7 \mathrm{H}_{2} \mathrm{O}\right)$ were purchased from Sigma-Aldrich. Reactive Black 5 (assigned as RB5) was obtained from ChemLab (NV).

\subsection{Preparation of Graphite Oxide (GO)}

The modified Hummers' method was used for the synthesis of graphite oxide (GO) by oxidation of graphite [41]. Briefly, graphite powder $(10 \mathrm{~g})$ was added under stirring in $230 \mathrm{~mL}$ of sulfuric acid at $0{ }^{\circ} \mathrm{C}$. Potassium permanganate $\left(\mathrm{KMnO}_{4}, 30 \mathrm{~g}\right)$ were slowly added in the mixture in order to prevent the increase of temperature $\left(<20^{\circ} \mathrm{C}\right)$. The reaction mixture was cooled to $2^{\circ} \mathrm{C}$ and stirring was followed at ambient temperature for $30 \mathrm{~min}$. Distilled water $(230 \mathrm{~mL})$ was added to the mixture at a slow rate under stirring for $15 \mathrm{~min}$, maintaining the temperature under $98^{\circ} \mathrm{C}$ and then, it was further diluted with $1.4 \mathrm{~L}$ of distilled water. Finally, $100 \mathrm{~mL}$ of hydrogen peroxide ( $30 \mathrm{wt} \%$ solution) was added into the mixture which was left overnight. The GO particles were separated by decantation and were freeze-dried. It is referred to as GO.

\subsection{Preparation of Modified Graphene Oxide}

For the synthesis of NGO, a specific amount of previously prepared graphite oxide $(2 \mathrm{~g})$ was dispersed in $175 \mathrm{~mL}$ of distilled water at an ultrasonic bath for $1 \mathrm{~h}$. The synthesis was followed by the dropwise addition of $\mathrm{NaOH}$ aqueous solution $(35 \mathrm{~mL}, 0.5 \mathrm{M})$ into the mixture under vigorous stirring. The suspension was transferred into a round bottom flask and kept at $90^{\circ} \mathrm{C}$ for $1 \mathrm{~h}$ under reflux. The solid product was separated by centrifugation, double washed with deionized water and ethanol and freeze-dried. The material is referred to as NGO.

\subsection{Preparation of $\mathrm{MnO}_{2}$ and $\mathrm{Mn}_{3} \mathrm{O}_{4}$}

For the preparation of $\mathrm{MnO}_{2}$, a quantity of $\mathrm{MnSO}_{4}(0.2 \mathrm{M})$ was added to $\mathrm{KMnO}_{4}(0.21 \mathrm{M})$ and was dissolved in distilled water $(30 \mathrm{~mL})$. Three followed steps included the 30-min stirring, centrifugation and freeze-drying. For the preparation of $\mathrm{Mn}_{3} \mathrm{O}_{4}$, the previously produced $\mathrm{MnO}_{2}$ was calcinated at $1000^{\circ} \mathrm{C}$ for $10 \mathrm{~h}$ with an increased temperature rate $10^{\circ} \mathrm{C} / \mathrm{min}$ [42].

\subsection{Synthesis of $\mathrm{NGO}-\mathrm{Mn}_{3} \mathrm{O}_{4}$, and $\mathrm{NGO}-\mathrm{MnO} \mathrm{O}_{2}$ Nanocomposites}

For the synthesis of NGO- $\mathrm{Mn}_{3} \mathrm{O}_{4}$, a specific amount of previously prepared graphite oxide ( $\left.8 \mathrm{~g}\right)$ was dispersed in distilled water with ultrasonication for $1 \mathrm{~h}$. Potassium permanganate $(3.2 \mathrm{~g})$ was dissolved in distilled water $(400 \mathrm{~mL})$ and was dropwise added to the $\mathrm{GO}$ suspension under vigorous stirring. The mixture was left overnight in the dark. After that, the mixture was ultrasonicated for $60 \mathrm{~min}$ and freshly prepared $\mathrm{NaOH}$ solution $(0.5 \mathrm{M}, 35 \mathrm{~mL})$ was added dropwise under stirring. The 
suspension was refluxed at $90^{\circ} \mathrm{C}$ for $1 \mathrm{~h}$. The solid product was washed with deionized water and ethanol and freeze-dried. For the preparation of the NGO- $\mathrm{MnO}_{2}$ composite, the amount of $\mathrm{KMnO}_{4}$ added was triple $(9.6 \mathrm{~g})$ than that used for $\mathrm{NGO}-\mathrm{Mn}_{3} \mathrm{O}_{4}$.

\subsection{Materials Characterization}

The morphology of the nanocomposite surface was investigated using a scanning electron microscope Zeiss Supra 55VP (Jena, Germany) at an increasing voltage of $15.00 \mathrm{kV}$ while, X-ray diffraction (XRD) was determined by a Philips PW 1820 diffractometer with a $\mathrm{Cu}$ Ka radiation from $20^{\circ}$ to $80^{\circ}$. In order to identify the functional groups of carbon surface, FTIR spectra (4000 to $400 \mathrm{~cm}^{-1}$ ) was depicted by a Perkin-Elmer 2000 FTIR spectrometer (Dresden, Germany) using KBr disks. The surface charge of materials was illustrated by potentiometric titration using an automatic titrator (Mettler Toledo T50). The measurements of Thermal Analysis (TA) were carried out with a Thermal Analyzer SDT 2960 under specific conditions $\left(25^{\circ} \mathrm{C}\right.$ to $1000^{\circ} \mathrm{C}$, increasing temperature rate $10^{\circ} \mathrm{C} / \mathrm{min}$ and helium atmosphere at $100 \mathrm{~mL} / \mathrm{min}$ ). The total percentage of $\mathrm{Mn}$ concentration of $\mathrm{NGO}-\mathrm{MnO}_{2}$ and NGO- $\mathrm{Mn}_{3} \mathrm{O}_{4}$ nanocomposites was performed using ICP-MS (Agilent 7500s-Agilent Technologies, Waldbronn, Germany).

\subsection{Degradation Experiments}

The removal of Reactive Black 5 from the aqueous phase, by $\mathrm{NGO}-\mathrm{Mn}_{3} \mathrm{O}_{4}$ and $\mathrm{NGO}-\mathrm{MnO}_{2}$ nanocomposites, was studied by batch experiments. Firstly, the effect of the solution $\mathrm{pH}$ on the catalytic performance of the composites prepared was investigated. Solutions of the dye were prepared with initial concentrations of $100 \mathrm{mg} / \mathrm{L}$, same volume $(20 \mathrm{~mL})$ and the same amount of catalysts $(0.01 \mathrm{~g})$ and the $\mathrm{pH}$ was adjusted between 3-9 with a $\mathrm{pH}$-meter (CRISON basic 20), by micro-additions of dilute $\mathrm{HCl}$ and $\mathrm{NaOH}$ solutions. The adjusted suspensions were shaken (at agitation rate $150 \mathrm{rpm}$ ) for $24 \mathrm{~h}$ at $25^{\circ} \mathrm{C}$ in a water bath with a shaker (JULABO SW-21C) and they were filtrated through a $0.45 \mu \mathrm{m}$ pore size membrane syringe filter (obtained by Schleicher-Schuell Micro Science). The remaining concentration of the dye was measured by UV-Vis. The removal percentage (R\%) of RB5 was calculated according to the Equation (1):

$$
R \%=\frac{C_{o}-C_{e}}{C_{o}} \times 100 \%
$$

where $C_{o}$ and $C_{e}(\mathrm{mg} / \mathrm{L})$ are the initial and equilibrium concentrations of Reactive Black 5, respectively. The optimum $\mathrm{pH}$ for the degradation experiments was found to be 3 .

Kinetic experiments took place by mixing $0.01 \mathrm{~g}$ of catalyst and $20 \mathrm{~mL}$ of $\mathrm{RB} 5$ solution $(\mathrm{Co}=$ 40 and $100 \mathrm{mg} / \mathrm{L}$ ), at optimum $\mathrm{pH}$ value. The suspensions were shaken in a water bath at $25^{\circ} \mathrm{C}$ (agitation rate $=150 \mathrm{rpm}$ ) in various adsorption time ( $5 \mathrm{~min}-24 \mathrm{~h}$ ), filtrated through $0.45 \mu \mathrm{m}$ pore size syringe filter and the remaining RB5 concentrations were measured by UV-Vis. All experiments were performed triplicate and the results presented are the mean value.

\section{Results and Discussion}

\subsection{Materials Characterization}

The nanocomposites prepared were characterized for their manganese concentration and the form of the impregnated manganese oxide, as well as their texture. The total Mn content for the NGO- $\mathrm{Mn}_{3} \mathrm{O}_{4}$ and NGO- $\mathrm{MnO}_{2}$ nanocomposites, estimated by ICP-MS found to be 10.4 and $19.2 \% \mathrm{w} / \mathrm{w}$.

The XRD patterns of $\mathrm{MnO}_{2}, \mathrm{NGO}, \mathrm{NGO}-\mathrm{MnO}_{2}$ and $\mathrm{Mn}_{3} \mathrm{O}_{4}, \mathrm{Mn}_{3} \mathrm{O}_{4}, \mathrm{NGO}-\mathrm{Mn}_{3} \mathrm{O}_{4}$, in comparison with the pattern of GO, are shown in Figure $1 \mathrm{a}, \mathrm{b}$, in order to provide information about their structure. The characteristic (001) peak of graphite oxide, obtained at $2 \theta=10.3^{\circ}$, is indicative of the successful transformation of graphite into graphite oxide [43]. This peak appeared to be lower in the pattern for NGO, indicative of a partial exfoliation of GO. 


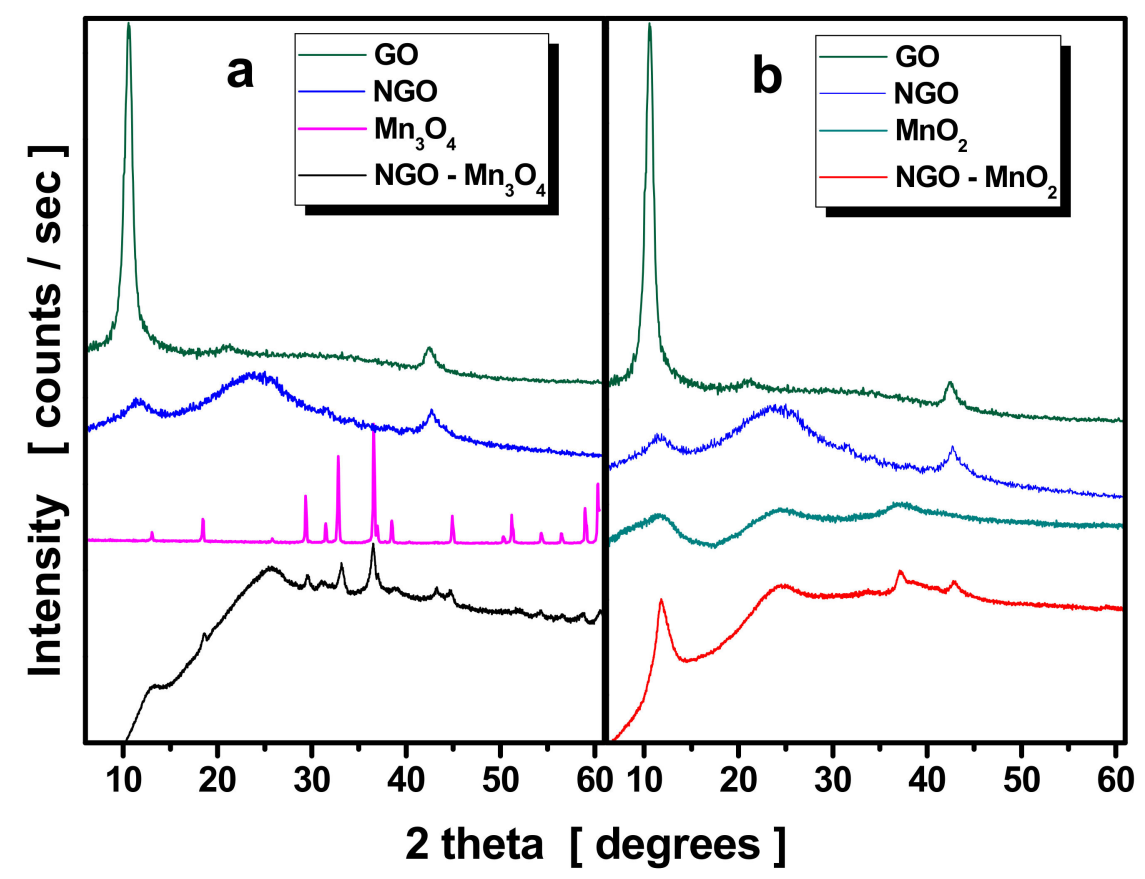

Figure 1. XRD patterns of: (a) graphene oxide (GO), modified graphene oxide (NGO), manganese oxide $\left(\mathrm{Mn}_{3} \mathrm{O}_{4}\right)$ and $\mathrm{NGO}-\mathrm{Mn}_{3} \mathrm{O}_{4}$ nanocomposite; (b) GO, modified graphene oxide (NGO), manganese oxide $\left(\mathrm{MnO}_{2}\right)$ and $\mathrm{NGO}-\mathrm{MnO}_{2}$ nanocomposite.

In the diffraction pattern of $\mathrm{MnO}_{2}$, the main reflections at $2 \theta=11.4^{\circ}, 25^{\circ}, 37.2^{\circ}$, and $66.7^{\circ}$ could be attributed to the (001), (002), (111) and (312) lattice planes of $\delta-\mathrm{MnO}_{2}$ (birnessite) respectively [44,45].

In addition, the broadened peaks indicated the low crystallinity of the manganese oxide. The average crystallite size (D) of $\mathrm{MnO}_{2}$ as calculated applying Debye Scherrer's equation for the (121) peak found to be about $35 \mathrm{~nm}$ [46]. The XRD pattern for the $\mathrm{NGO}-\mathrm{MnO}_{2}$ composite presented the characteristic peaks of $\delta-\mathrm{MnO}_{2}$. Besides, the absence of the peak at $2 \theta=10.3^{\circ}$, indicated the complete exfoliation of GO during the preparation of the nanocomposite. The XRD pattern of $\mathrm{Mn}_{3} \mathrm{O}_{4}$ presented peaks at $2 \theta 18^{\circ}(101), 29^{\circ}(112), 32.5^{\circ}(103), 37.2^{\circ}(211), 45^{\circ}(220)$ and $60^{\circ}$ (224), characteristic for $\mathrm{Mn}_{3} \mathrm{O}_{4}$ [47]. For the NGO- $\mathrm{Mn}_{3} \mathrm{O}_{4}$ composite, similar peaks to those appeared in the diffraction pattern for $\mathrm{Mn}_{3} \mathrm{O}_{4}$ [48] revealed the formation of $\mathrm{Mn}_{3} \mathrm{O}_{4}$. The diffraction peak at $25.6^{\circ}$ indicated a partial reduction of graphene oxide $[49,50]$.

The $\mathrm{N}_{2}$ adsorption isotherms for the NGO- $\mathrm{Mn}_{3} \mathrm{O}_{4}$ and $\mathrm{NGO}-\mathrm{MnO}_{2}$ nanocomposites are shown in Figure 2 while the pore size distribution in the inset of Figure 2. The isotherms of the nanocomposites indicate an absence of variation in nitrogen uptake, corresponding to a deficiency of micropores. The nanocatalyst $\mathrm{NGO}-\mathrm{Mn}_{3} \mathrm{O}_{4}$ presented an isotherm of type IV, according to the IUPAC classification, indicative of the presence of mesopores. Furthermore, the isotherm exhibited a hysteresis loop at relative pressure $\mathrm{P} / \mathrm{Po}=0.70-0.99$, classified as $\mathrm{H} 3$. The specific surface area was measured by the BET method and found to be $7.52 \mathrm{~m}^{2} / \mathrm{g}$, while the pore volume found to be $0.056 \mathrm{~cm}^{3} / \mathrm{g}$. These values are in agreement with the characteristics of hysteresis loop, indicative of lack of micropores. The $\mathrm{N}_{2}$ adsorption/desorption isotherms for $\mathrm{NGO}-\mathrm{MnO}_{2}$ revealed lack of micropores while the increased $\mathrm{N}_{2}$ uptake presented at $\mathrm{P} / \mathrm{Po}>0.95$ is indicative of external surface area and the hysteresis loop at relative pressure $\mathrm{P} / \mathrm{Po}=\sim 0.50-0.99$ is indicative of the mesopores. 


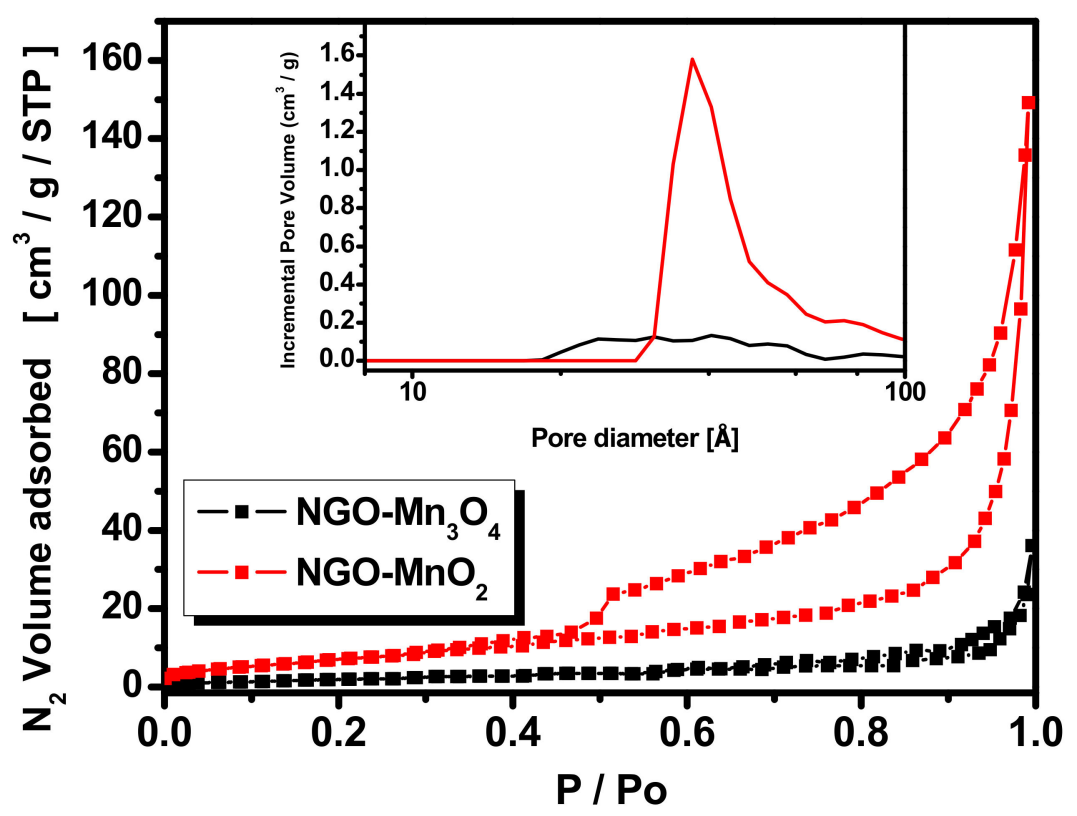

Figure 2. $\mathrm{N}_{2}$ adsorption isotherms and pore diameter distribution (inset) for $\mathrm{NGO}-\mathrm{Mn}_{3} \mathrm{O}_{4}$ and $\mathrm{NGO}-\mathrm{MnO}_{2}$ modified composites.

The textural parameters of NGO- $\mathrm{Mn}_{3} \mathrm{O}_{4}$ and $\mathrm{NGO}-\mathrm{MnO}_{2}$ nanocomposites are presented in Table 1 along with the parameters of $\mathrm{NGO}, \mathrm{Mn}_{3} \mathrm{O}_{4}$ and $\mathrm{MnO}_{2}$, for the sake of comparison. From the Table, it is seen that the NGO- $\mathrm{MnO}_{2}$ nanocomposite presented increase mesopores volume as well as increase Specific Surface Area. This can be due to the fact that $\mathrm{NaOH}$ modification tuned the oxygen surface functional groups and expanded the graphene layers resulting in more decays and porous structure [51]. From the above results, it can be concluded that the better catalytic performance of the NGO- $\mathrm{MnO}_{2}$ composite may be attributed to the increased specific surface area and mesopores volume, that contributed to an increase RB5 adsorption.

Table 1. Textural parameters of the manganese oxides, of $\mathrm{NGO}$ and of $\mathrm{NGO}-\mathrm{Mn}_{3} \mathrm{O}_{4}$ and NGO- $\mathrm{MnO}_{2}$ nanocomposites.

\begin{tabular}{ccccc}
\hline Samples & $\mathbf{S}_{\text {BET }}\left(\mathbf{m}^{2} / \mathbf{g}\right)$ & $\mathbf{V}_{\mathbf{t}}\left(\mathbf{c m}^{\mathbf{3}} / \mathbf{g}\right)$ & $\mathbf{V}_{\text {meso }}\left(\mathbf{c m}^{\mathbf{3}} / \mathbf{g}\right)$ & $\mathbf{V}_{\text {mic }}\left(\mathbf{c m}^{\mathbf{3}} / \mathbf{g}\right)$ \\
\hline $\mathrm{NGO}$ & 9.10 & 0.080 & 0.080 & 0 \\
$\mathrm{Mn}_{3} \mathrm{O}_{4}$ & 2.38 & 0.014 & 0.014 & 0 \\
$\mathrm{MnO}_{2}$ & 38.50 & 0.336 & 0.336 & 0 \\
$\mathrm{NGO}_{2} \mathrm{Mn}_{3} \mathrm{O}_{4}$ & 7.52 & 0.056 & 0.056 & 0 \\
$\mathrm{NGO}^{-\mathrm{MnO}_{2}}$ & 118.12 & 0.231 & 0.231 & 0 \\
\hline
\end{tabular}

\subsection{Degradation of Reactive Black 5}

The prepared nanocomposites were tested for the RB5 degradation efficiency. Thus, the effect of parameters such as $\mathrm{pH}$, initial RB5 concentration and contact time were examined.

\subsubsection{Effect of $\mathrm{pH}$}

The effect of solution $\mathrm{pH}$ on RB5 removal/degradation was examined in the $\mathrm{pH}$ range of 3-9 and the results are illustrated in Figure 3. From the Figure it is seen that the degradation efficiency decreased with the $\mathrm{pH}$ increase $\left(89 \%\right.$ at $\mathrm{pH} 3.0$ to $43 \%$ at $\mathrm{pH} 9.0$ for $\mathrm{MnO}_{2}$ ), indicating that the degradation of $\mathrm{RB} 5$ by the under-examination materials is facilitated in acidic solutions. Oxidation of organic pollutants by $\mathrm{Mn}_{3} \mathrm{O}_{4}$ and $\mathrm{MnO}_{2}$ is usually $\mathrm{pH}$-dependent, because of the $\mathrm{pH}$-dependent redox potential of $\mathrm{MnO}_{2} / \mathrm{Mn}^{2+}$ and the speciation of organic pollutants [52]. This dependence may be attributed to the fact that $\mathrm{MnO}_{2}$ requires the involvement of protons to be reduced to $\mathrm{Mn}^{2+}$ and/or to the fact that the 
RB5 oxidation is considered a surface reaction connected to the surface chemistry and charge of the materials involved [53].

The importance of the solution $\mathrm{pH}$ is due to the fact that it impacts the surface charge of the supporting material that acts as adsorbent (NGO). The pKa values of RB5 found to be almost close to 3.8 and 6.9. The $\mathrm{pKa}$ of the sodium sulfonate groups ( $-\mathrm{SO}_{3} \mathrm{Na}$ i. e. sulfonic groups) attached to the dye molecules are known to be very low and can reach negative values, while the pKa value of 3.8 is close to the pKa of aniline (i.e., 4.6) and can be attributed to the $-\mathrm{NH}_{2}$ groups of the dye molecules. This means that at $\mathrm{pH}$ lower than 3.8 and higher than the $\mathrm{pKa}$ of the sulfonate groups, the dye molecules are in their anionic forms and have got the highest negative charge. From the potentiometric titrations results the nanocomposites' surface is positively charged at $\mathrm{pH}$ lower than this value [40]. Thus, in acidic medium, the electrostatic attractions between the anionic dyes and the positively charged surface of the nanocomposites are maximized, so that the $\mathrm{pH}$-dependent adsorption isotherms of the dye show nanocomposites' surface by $\pi-\pi$ and hydrophobic interactions as well as by electrostatic attractions. Since the maximum decolorization occurred at $\mathrm{pH} 3$, equilibrium and kinetic experiments were performed at this $\mathrm{pH}$.


Figure 3. (a) Effect of initial $\mathrm{pH}$ on $\mathrm{RB} 5$ adsorption/degradation onto $\mathrm{NGO}, \mathrm{MnO}_{2}, \mathrm{Mn}_{3} \mathrm{O}_{4}, \mathrm{NGO}-\mathrm{Mn}_{3} \mathrm{O}_{4}$ and NGO- $\mathrm{MnO}_{2}$ nanocomposites $(\mathrm{Co}=100 \mathrm{mg} / \mathrm{L}, \mathrm{m}=0.01 \mathrm{~g}, \mathrm{~V}=0.02 \mathrm{~L})$; (b) potentiometric titration results for the nanocomposite catalysts. 


\subsubsection{Effect of Initial Concentration of RB5}

Experiments addressing the effect of the RB5 initial concentration were performed for pure manganese oxides $\left(\mathrm{MnO}_{2}\right.$ and $\left.\mathrm{Mn}_{3} \mathrm{O}_{4}\right)$, pure GO (for comparison) and $\mathrm{NGO}$ as well as for $\mathrm{NGO}-\mathrm{Mn}_{3} \mathrm{O}_{4}$ and NGO- $\mathrm{MnO}_{2}$ nanocomposites in order the maximum removal ability of the catalysts to be estimated; the results are presented in Figure 4. Since the RB5 removal mechanism on the nanocomposite is expected to be complex and to involve adsorption and degradation, the RB5 removal curves were not fitted to any theoretical isotherm. The removal results in Figure 4 indicate that the application of the nanocatalysts at $\mathrm{pH} 3$ presented an increase dye removal with the $\mathrm{NGO}-\mathrm{MnO}_{2}$ to present the highest one. The removal for NGO- $\mathrm{MnO}_{2}$ was about $600 \mathrm{mg}$ RB5 per gram of the solid material while the order of the removal was GO, $\mathrm{Mn}_{3} \mathrm{O}_{4}<\mathrm{NGO}<\mathrm{MnO}_{2}<\mathrm{NGO}-\mathrm{Mn}_{3} \mathrm{O}_{4}<\mathrm{NGO}-\mathrm{MnO}_{2}$. The removal for NGO found to be about $300 \mathrm{mg}$ RB5/g while for pure GO was about $150 \mathrm{mg} / \mathrm{g}$ this increase can be due to the surface chemistry changes of $\mathrm{GO}$ after the $\mathrm{NaOH}$ modification that led to lower oxygen surface functional groups enhancing this way the adsorption of RB5 molecules. For both nanocomposites, the maximum removal they achieved was higher than that of their precursors.

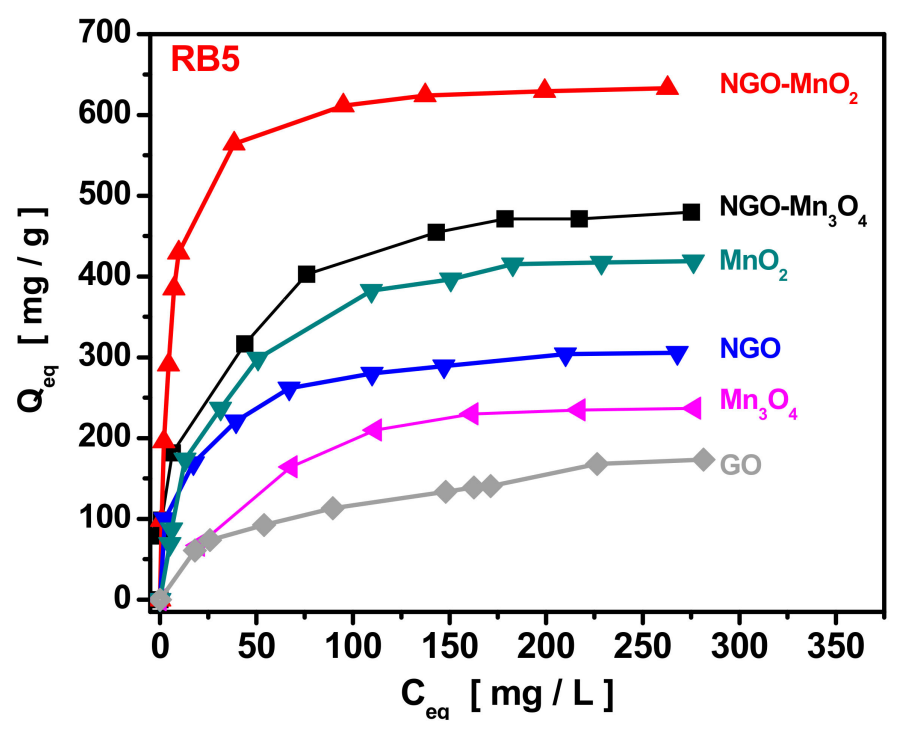

Figure 4. Effect of initial concentration of $\mathrm{RB} 5(\mathrm{pH}=3, \mathrm{~m}=0.01 \mathrm{~g}, \mathrm{~V}=0.02 \mathrm{~L})$.

\subsubsection{Effect of Contact Time}

The kinetic experiments were carried out in aqueous solutions of RB5 for two different initial concentrations ( 40 and $100 \mathrm{mg} / \mathrm{L}$ ) in absence (non radical oxidation) and presence (radical oxidation) of $\mathrm{H}_{2} \mathrm{O}_{2}$. The appropriate for complete mineralization concentration of $\mathrm{H}_{2} \mathrm{O}_{2}$ found to be $0.15 \mathrm{M}$, estimated from the equation:

$$
2 \mathrm{C}_{26} \mathrm{H}_{21} \mathrm{O}_{19} \mathrm{~N}_{5} \mathrm{~S}_{6} \mathrm{Na}_{4}+87 \mathrm{H}_{2} \mathrm{O}_{2} \rightarrow 52 \mathrm{CO}_{2}+108 \mathrm{H}_{2} \mathrm{O}+8 \mathrm{Na}+10 \mathrm{~N}+12 \mathrm{~S}
$$

From the experimental results shown in Figures 5 and 6, equilibrium was attained at 60 min for all samples. The nanocomposites presented higher removal than the pure manganese oxides, indicating an improved decolorization, may be due to the synergetic effect of adsorption-oxidation.

The pseudo-first order (dashed lines) and pseudo-second order (compact lines) kinetic models were fitted to the experimental results and the kinetic parameters, as well as the goodness of the fit, are presented in Table 2. From the Table, it is concluded that pseudo-second order kinetic model presented a better fit and $\mathrm{R}^{2}$ indicative of a synergetic adsorption-degradation mechanism and not a neat degradation. 

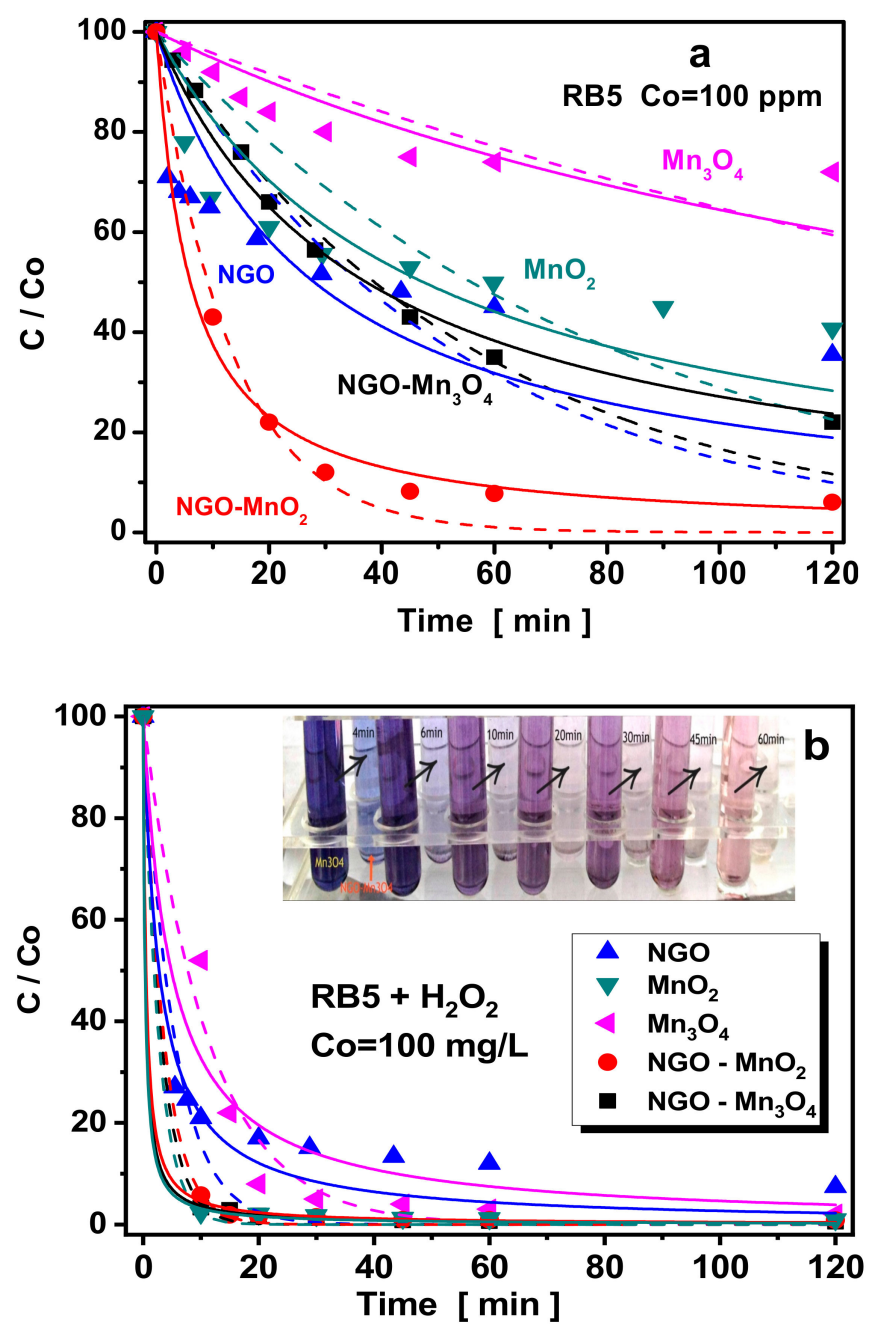

Figure 5. (a,b) Effect of contact time on the degradation of RB5 on $\mathrm{NGO}, \mathrm{MnO}_{2}, \mathrm{Mn}_{3} \mathrm{O}_{4}, \mathrm{NGO}-\mathrm{Mn}_{3} \mathrm{O}_{4}$ and NGO- $\mathrm{MnO}_{2}$ nanocomposites for initial RB5 concentration of $100 \mathrm{mg} / \mathrm{L}$ (a) in presence and (b) absence of $\mathrm{H}_{2} \mathrm{O}_{2}(\mathrm{Co}=100 \mathrm{mg} / \mathrm{L}, \mathrm{pH}=3, \mathrm{~m}=0.01 \mathrm{~g}, \mathrm{~V}=0.02 \mathrm{~L})$. (inset: decolorization after $60 \mathrm{~min}$ for $\mathrm{Mn}_{3} \mathrm{O}_{4}$ in the first row and $\mathrm{NGO}-\mathrm{MnO}_{2}$ in the second row).

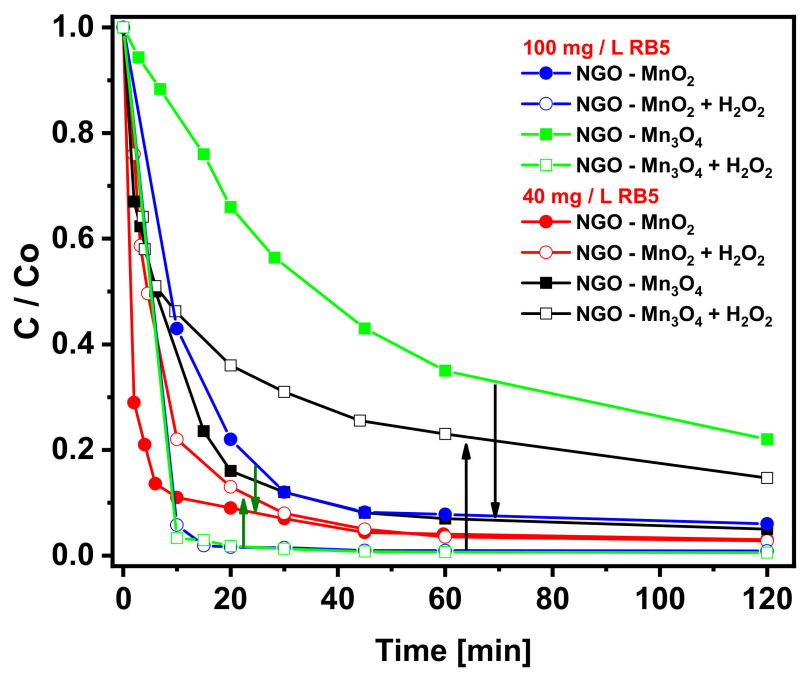

Figure 6. Effect of contact time on the degradation of RB5 on $\mathrm{NGO}-\mathrm{Mn}_{3} \mathrm{O}_{4}$ and $\mathrm{NGO}-\mathrm{MnO}_{2}$ nanocomposites for initial RB5 concentration of $40 \mathrm{mg} / \mathrm{L}$ and $100 \mathrm{mg} / \mathrm{L}$ in presence (radical) and absence (non-radical) of $\mathrm{H}_{2} \mathrm{O}_{2}(\mathrm{pH}=3, \mathrm{~m}=0.01 \mathrm{~g}, \mathrm{~V}=0.02 \mathrm{~L}$ ). 
Table 2. Kinetic parameters.

\begin{tabular}{|c|c|c|c|c|c|}
\hline \multirow{2}{*}{ Samples } & \multirow{2}{*}{ Co } & \multicolumn{2}{|c|}{ Pseudo-First Order } & \multicolumn{2}{|c|}{ Pseudo-Second Order } \\
\hline & & $K_{1}$ & $\mathbf{R}^{2}$ & $\mathrm{~K}_{2}$ & $\mathbf{R}^{2}$ \\
\hline \multirow{2}{*}{ NGO } & 100 & $1.92 \times 10^{-2}$ & 0 & $3.60 \times 10^{-4}$ & 0.393 \\
\hline & $100+\mathrm{H}_{2} \mathrm{O}_{2}$ & $1.85 \times 10^{-1}$ & 0.857 & $3.63 \times 10^{-3}$ & 0.961 \\
\hline \multirow{2}{*}{$\mathrm{MnO}_{2}$} & 100 & $1.91 \times 10^{-2}$ & 0.371 & $2.10 \times 10^{-4}$ & 0.691 \\
\hline & $100+\mathrm{H}_{2} \mathrm{O}_{2}$ & $3.73 \times 10^{-1}$ & 0.998 & $3.09 \times 10^{-2}$ & 0.999 \\
\hline \multirow{2}{*}{$\mathrm{Mn}_{3} \mathrm{O}_{4}$} & 100 & $4.30 \times 10^{-3}$ & 0.504 & $5.00 \times 10^{-5}$ & 0.66 \\
\hline & $100+\mathrm{H}_{2} \mathrm{O}_{2}$ & $8.97 \times 10^{-2}$ & 0.972 & $2.10 \times 10^{-3}$ & 0.924 \\
\hline \multirow{4}{*}{$\mathrm{NGO}-\mathrm{MnO}_{2}$} & 100 & $7.60 \times 10^{-2}$ & 0.982 & $1.60 \times 10^{-3}$ & 0.999 \\
\hline & $100+\mathrm{H}_{2} \mathrm{O}_{2}$ & $2.80 \times 10^{-1}$ & 0.999 & $2.08 \times 10^{-2}$ & 0.999 \\
\hline & 40 & $4.78 \times 10^{-1}$ & 0.939 & $2.58 \times 10^{-2}$ & 0.991 \\
\hline & $40+\mathrm{H}_{2} \mathrm{O}_{2}$ & $1.47 \times 10^{-1}$ & 0.984 & $0.61 \times 10^{-2}$ & 0.983 \\
\hline \multirow{4}{*}{$\mathrm{NGO}-\mathrm{Mn}_{3} \mathrm{O}_{4}$} & 100 & $1.79 \times 10^{-2}$ & 0.977 & $2.70 \times 10^{-4}$ & 0.999 \\
\hline & $100+\mathrm{H}_{2} \mathrm{O}_{2}$ & $3.20 \times 10^{-1}$ & 0.998 & $2.66 \times 10^{-2}$ & 0.999 \\
\hline & 40 & $1.14 \times 10^{-1}$ & 0.950 & $0.52 \times 10^{-2}$ & 0.993 \\
\hline & $40+\mathrm{H}_{2} \mathrm{O}_{2}$ & $0.67 \times 10^{-1}$ & 0.590 & $0.29 \times 10^{-2}$ & 0.898 \\
\hline
\end{tabular}

As presented in Figure $5 b$ the presence of $\mathrm{H}_{2} \mathrm{O}_{2}$ increased the RB5 degradation. This could be attributed to the effect of $\bullet \mathrm{OH}$ radicals that could be enhanced by the increase concentration of $\mathrm{H}_{2} \mathrm{O}_{2}$. For this reason, the influence of different doses of $\mathrm{H}_{2} \mathrm{O}_{2}$ concentration on RB5 oxidative degradation was investigated, and the results are presented in Figure 7a. From this Figure, it is concluded that with the increase of $\mathrm{H}_{2} \mathrm{O}_{2}$ dose from $0.05 \mathrm{mM}$ until the concentration of $0.15 \mathrm{mM}$, the RB5 degradation increases. In non-radical oxidation, the nanocomposites presented a better performance than the respective manganese oxides while in radical oxidation their performance was similar (Figure 5b).

The contribution of $\mathrm{OH}$ radicals to RB5 degradation was examined by adding methanol to the suspension as scavenger. In Figure $7 \mathrm{~b}$ the influence of different concentrations of methanol as a quenching agent is presented. As seen from the Figure, the increase of methanol volume results to a decrease of RB5 degradation. It can be concluded that $\mathrm{OH} \bullet$ radicals are generated during the reaction, react rapidly with methanol, resulting in the decrease of RB5 oxidation. Both nanocomposites showed similar decrease. The effect of the scavenging leads to the conclusion that surface-bound $\mathrm{OH} \bullet$ play the dominant role in the RB5 degradation.

The possible reuse of the loaded materials was studied, in order to assess the environmental safety of the composites, for this reason, the elution ability was tested for the nanocomposites and the results are presented in Figure 8. Deionized water, at a range of $\mathrm{pH}$ values (Figure 8a), as well as ethanol, methanol and acetonitrile (Figure $8 b$ ) were used as eluents for RB5 elution from loaded NGO- $\mathrm{Mn}_{3} \mathrm{O}_{4}$ and NGO- $\mathrm{MnO}_{2}$ nanocomposites. The maximum desorption capacity for NGO- $\mathrm{Mn}_{3} \mathrm{O}_{4}$ and NGO- $\mathrm{MnO}_{2}$ that was found about $4.2 \%$ and $6.1 \%$ of the removed $\mathrm{RB} 5$ respectively, was noticed at $\mathrm{pH}$ 9.0, where the RB5 retention forces were deteriorated, conflicting to adsorption that found to be more effective at $\mathrm{pH} 3.0$.

The organic solvents that were also tested for RB5 elution from the nanocomposites, found to be less effective than deionized water at $\mathrm{pH}=9.0$, with methanol to be the optimal eluent. The low desorption capacity led to the conclusion that the amount of RB5 eluted from the used nanocomposites are in agreement with the total non-degradated dye. 

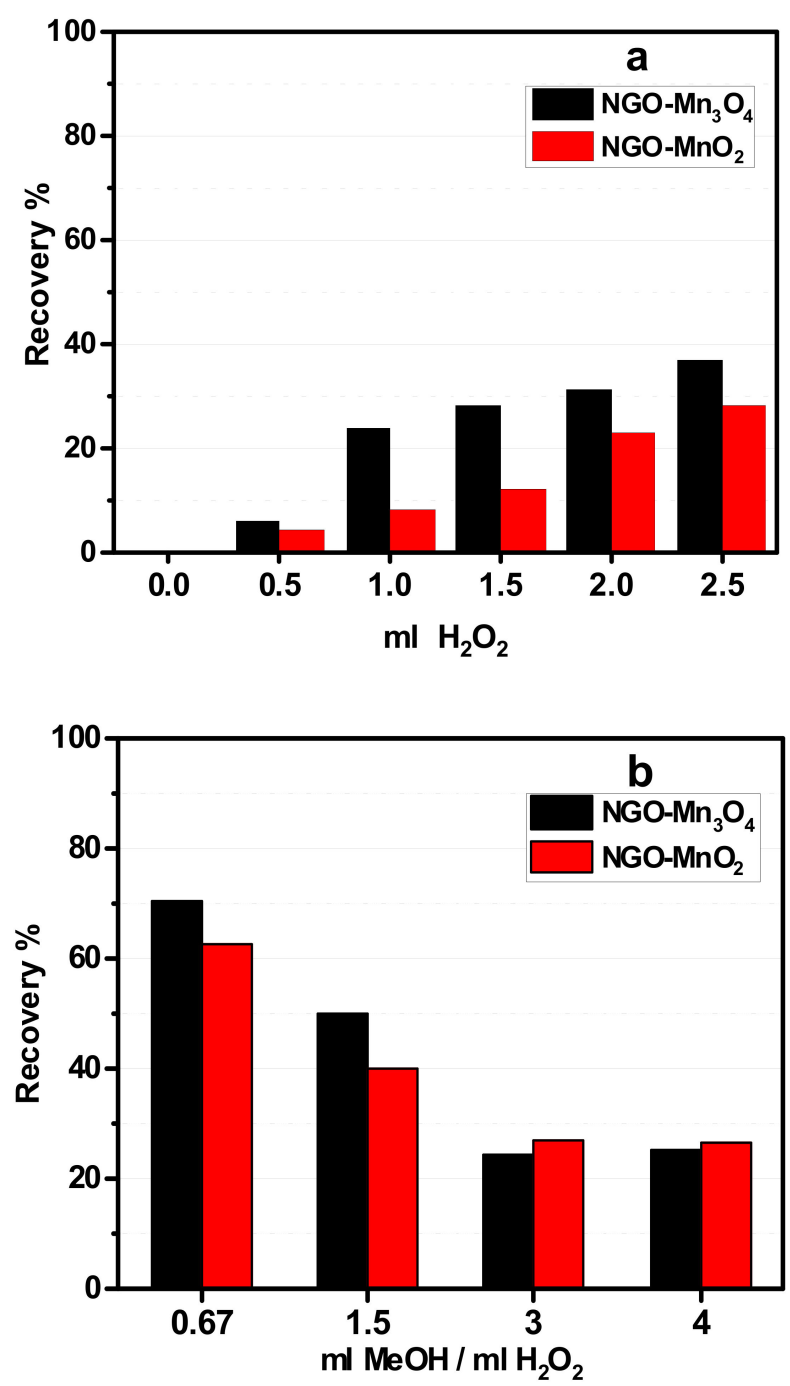

Figure 7. Effect of (a) $\mathrm{H}_{2} \mathrm{O}_{2}$ concentration and (b) methanol/ $\mathrm{H}_{2} \mathrm{O}_{2}$ ratio on $\mathrm{RB} 5$ degradation by NGO- $\mathrm{Mn}_{3} \mathrm{O}_{4}$ and NGO- $\mathrm{MnO}_{2}$ nanocomposites ( $\mathrm{Co}=100 \mathrm{mg} / \mathrm{L}, \mathrm{pH}=3, \mathrm{~m}=0.01 \mathrm{~g}, \mathrm{~V}=0.02 \mathrm{~L}$ ).
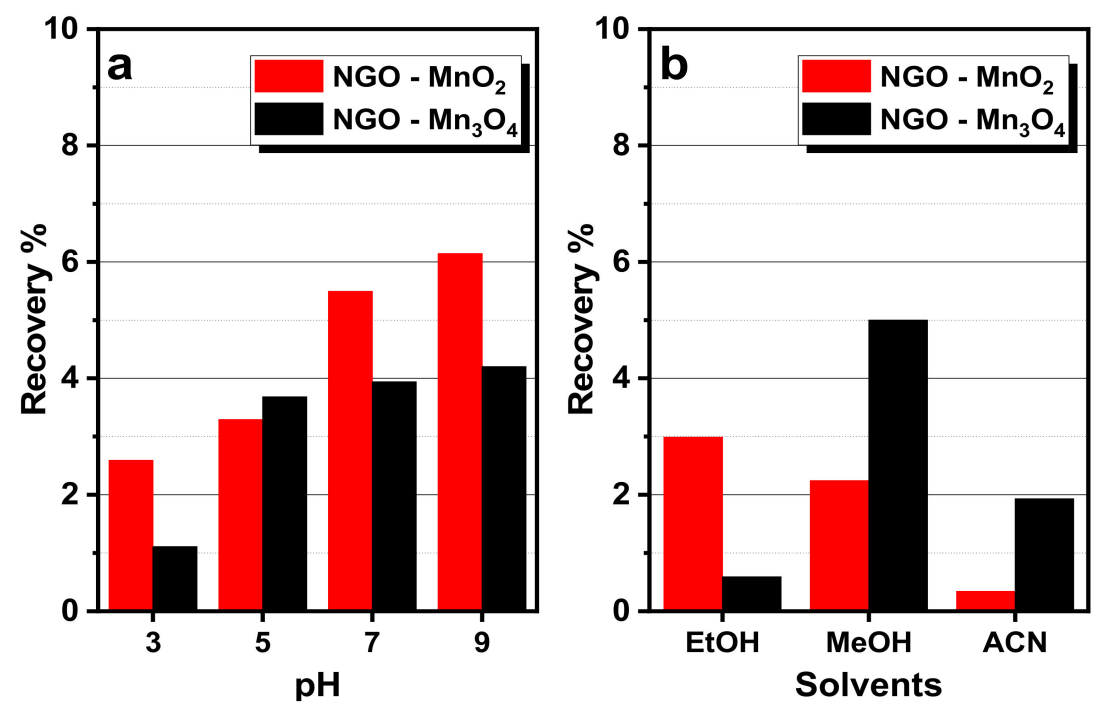

Figure 8. Elution experiments by (a) deionized water (b) ethanol, methanol and acetonitrile of the loaded the $\mathrm{NGO}-\mathrm{MnO}_{2}$ and $\mathrm{NGO}-\mathrm{Mn}_{3} \mathrm{O}_{4}$ nanocomposites $(\mathrm{Co}=100 \mathrm{mg} / \mathrm{L}, \mathrm{m}=0.01 \mathrm{~g}, \mathrm{~V}=0.02 \mathrm{~L}$ ). 
For the examination of the reuse of the nanocomposites, the spent materials were eluted with methanol and reused for further application for 5 cycles. The results are presented in Figure 9. The decrease of their gradual degradation ability during the 5 cycles may be attributed either to the elution of $\mathrm{Mn}$ in the solution during the degradation that resulted to the reduction of their efficiency or to the oxidation of the RB5 into smaller molecules that were adsorbed on the nanocomposites' surface, having as a consequence their pore blocking and the decrease of their further adsorption ability.

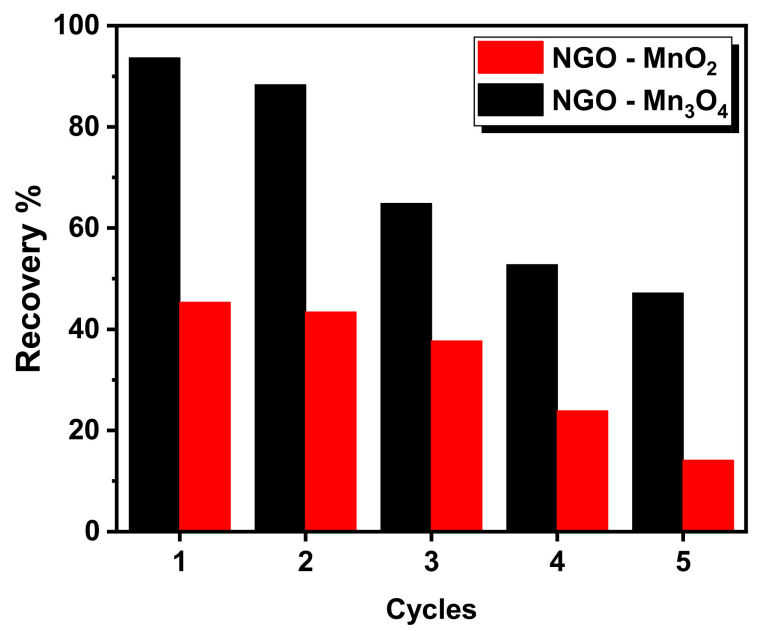

Figure 9. Recovery efficiency of the $\mathrm{NGO}-\mathrm{MnO}_{2}$ and $\mathrm{NGO}-\mathrm{Mn}_{3} \mathrm{O}_{4}$ after 5 cycles of adsorptiondesorption $(\mathrm{Co}=100 \mathrm{mg} / \mathrm{L}, \mathrm{pH}=3, \mathrm{~m}=0.01 \mathrm{~g}, \mathrm{~V}=0.02 \mathrm{~L})$.

For the examination of the materials' stability the leaching of manganese in the solution, after RB5 degradation for $2 \mathrm{~h}$, was examined and the measurements of the manganese in the reaction solutions were performed by ICP. From the results, presented in Table 3, it is shown the low percentage of the eluted manganese in the solution compared to the Mn concentration in the material, as well as the stability of the materials and the beneficial effect of the NGO support during the RB5 degradation.

Table 3. Leaching of manganese in the solution after RB5 degradation.

\begin{tabular}{|c|c|c|}
\hline & \multicolumn{2}{|c|}{ Mn \% Leaching in the Solution } \\
\hline & & $+\mathrm{H}_{2} \mathrm{O}_{2}$ \\
\hline $\mathrm{Mn}_{3} \mathrm{O}_{4}$ & 8.5 & 6.6 \\
\hline $\mathrm{NGO}-\mathrm{Mn}_{3} \mathrm{O}_{4}$ & 1.6 & 3.3 \\
\hline $\mathrm{MnO}_{2}$ & 8.4 & 9.5 \\
\hline $\mathrm{NGO}-\mathrm{MnO}_{2}$ & 1.0 & 4.8 \\
\hline
\end{tabular}

The FT-IR spectra of NGO support and of the nanocomposites prepared, presented in Figure 10, provide information about their surface chemistry before (black line) and after the degradation of RB5 (red line). For the NGO support, the spectrum shows bands at 1110, 1228, 1370, 1460, and $1580 \mathrm{~cm}^{-1}$ that may correspond to alkoxy, epoxy and carboxyl groups, respectively [54]. The spectrum of NGO- $\mathrm{Mn}_{3} \mathrm{O}_{4}$ nanocomposite, revealed that the carboxyl bands of NGO were not visible, may be due to their participation as nucleation centers and/or as a consequence of the thermal treatment during the synthesis. The broadness of the band at about $1200 \mathrm{~cm}^{-1}$, attributed to $\mathrm{C}-\mathrm{O}$ bonds, may illustrate the presence of -OH groups on the surface of NGO. The peaks at $1450 \mathrm{~cm}^{-1}$ are indicative of stable forms of chemisorbed oxygen, while the bands at 621 and $592 \mathrm{~cm}^{-1}$ are characteristic of the Mn-O stretching modes of the manganese oxide nanoparticles and reveal the successful impregnation of manganese oxide into the carbon matrix. 

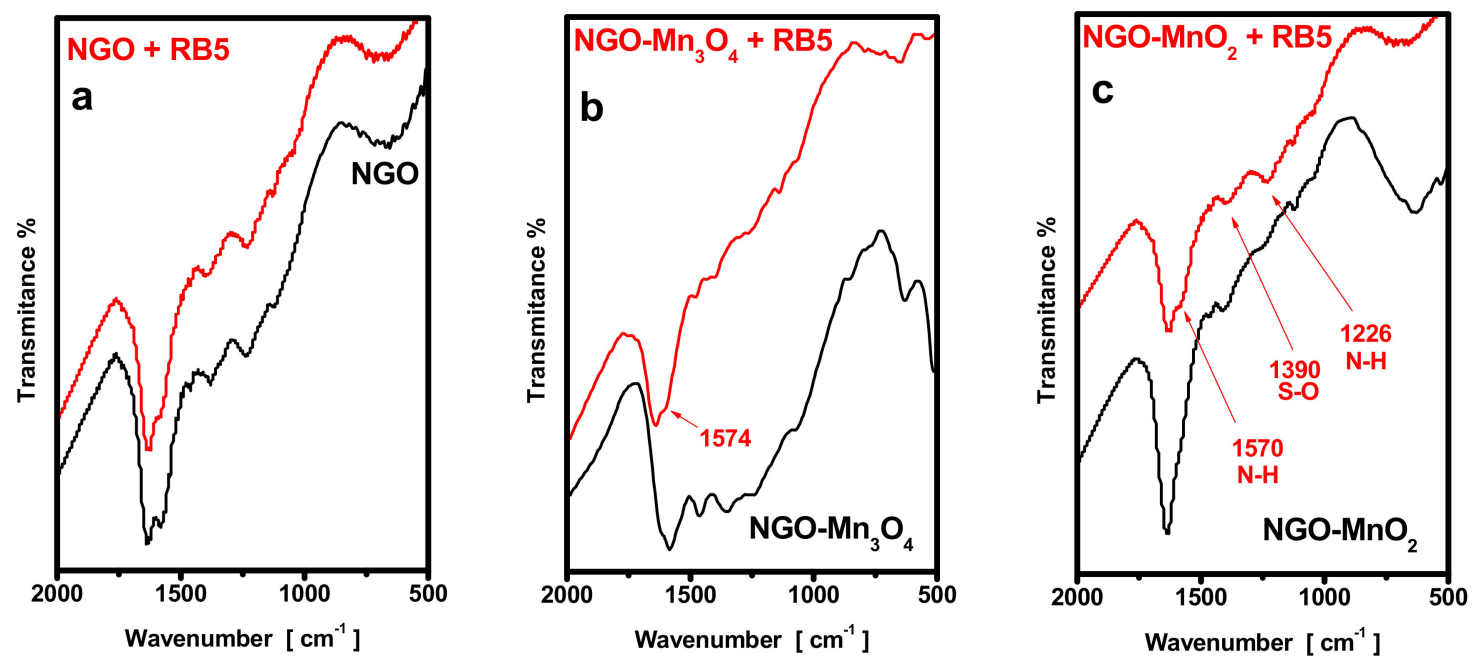

Figure 10. FTIR patterns of raw (black line) and after the RB5 degradation (red line) of NGO (a); NGO- $\mathrm{Mn}_{3} \mathrm{O}_{4}$ (b) and NGO- $\mathrm{MnO}_{2}$ (c) in presence of $\mathrm{H}_{2} \mathrm{O}_{2}$.

The spectra of the nanocomposites after the degradation of RB5, reveals bands that may be attributed to reaction products formed after the reaction between the dye and their functional groups. The shoulder appeared at $\sim 1574 \mathrm{~cm}^{-1}$ and the bands at $\sim 1226 \mathrm{~cm}^{-1}$ could be attributed to N-H bending and C-N bond respectively, as a result of the cleavage of the $-\mathrm{N}=\mathrm{N}$ - bond of the dye that resulted to the formation of primary amines. The bands at $\sim 1390 \mathrm{~cm}^{-1}$ revealed the presence of surface species with sulfone and/or sulfonate groups indicative of RB5 degradation. Similar results have been presented by Mbarek et al. after degradation of $\mathrm{RB} 5$ by $\mathrm{Mn}_{85} \mathrm{Al}_{15}$ particles [55] as well as by Méndez-Martınéz et al., [56] after electrochemical treatment of RB5 solution.

In order to further investigate the nature of nanocomposites and the alterations of the surface chemistry after the degradation of RB5, differential thermal gravimetric measurements (DTG) were implied between 25 and $1000{ }^{\circ} \mathrm{C}$ in nitrogen (Figure 11). For all samples, the peaks appeared at 100 and $200^{\circ} \mathrm{C}$ represented the removal of physically adsorbed water and the dehydration of crystal water interlayer water in the nanostructure of manganese oxide phase/and or NGO, [57] respectively.

In Figure 11, the peaks representing the changes for the $\mathrm{NGO}-\mathrm{Mn}_{3} \mathrm{O}_{4}$ nanocomposite are presented. The peak at about $430^{\circ} \mathrm{C}$ could be attributed to reduction of $\mathrm{Mn}_{3} \mathrm{O}_{4}$ to $\mathrm{Mn}$ (II). $\mathrm{Mn}_{3} \mathrm{O}_{4}\left(\mathrm{Mn}_{1}+\mathrm{II}, \mathrm{Mn}_{2}+\mathrm{III}\right)$ can be transformed into $\mathrm{Mn}_{5} \mathrm{O}_{8}\left(\mathrm{Mn}_{2}+\mathrm{II}, \mathrm{Mn}_{3}+\mathrm{IV}\right)$ in the temperature range of 450-500 ${ }^{\circ} \mathrm{C}$ [58]. After release of oxygen, due to the reduction of $\mathrm{Mn}_{5} \mathrm{O}_{8}$ to $\mathrm{Mn}_{2} \mathrm{O}_{3}$ occurs and $\mathrm{Mn}$ (II) is finally reduced to $\mathrm{Mn}^{\circ}$ at about $740^{\circ} \mathrm{C}$. For the modified graphene oxide supported nanocomposites, the patterns appeared complex since the graphene phase is expected to participate in the reduction. In Figure 11a, the changes for the NGO- $\mathrm{Mn}_{3} \mathrm{O}_{4}$ nanocomposite, after the degradation of RB5, are also shown.

After the degradation of RB5, the relative intensity of the peaks corresponding to $\mathrm{Mn}_{3} \mathrm{O}_{4}$ and $\mathrm{Mn}$ (II) was different than that for the initial sample. Also, a peak corresponding to the reduction of $\mathrm{Mn}(\mathrm{II})$ to $\mathrm{Mn}^{\circ}$ was detected.

Concerning the nanocomposite $\mathrm{NGO}-\mathrm{MnO}_{2}$, a peak at the $800-840{ }^{\circ} \mathrm{C}$, related to $\mathrm{Mn}(\mathrm{II})$, is shown. The complex peaks between 300 and $600^{\circ} \mathrm{C}$ may present the reduction of $\mathrm{Mn}$ (IV) to $\mathrm{Mn}$ (II) with loss of oxygen [59]. $\mathrm{MnO}_{2}$ is reduced to $\mathrm{Mn}_{2} \mathrm{O}_{3}$ and then to $\mathrm{Mn}_{3} \mathrm{O}_{4}$ and $\mathrm{MnO}$. Then, $\mathrm{Mn}(\mathrm{II})$ is reduced between 750 and $800{ }^{\circ} \mathrm{C}$. There is no peak at about $200-250{ }^{\circ} \mathrm{C}$ indicative to the mass loss from the removal of the oxygen- containing functional surface groups. 


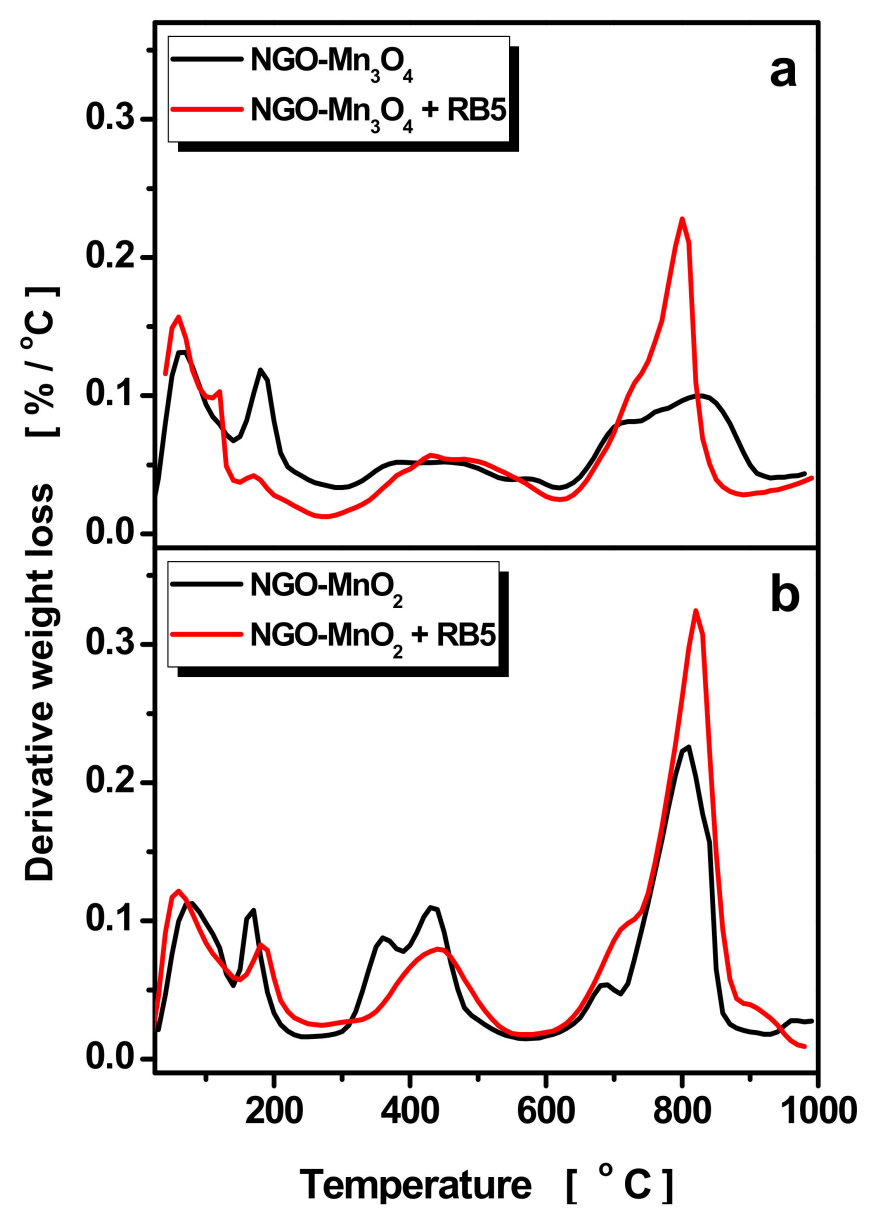

Figure 11. DTG curves for (a) $\mathrm{NGO}-\mathrm{Mn}_{3} \mathrm{O}_{4}$ and (b) $\mathrm{NGO}-\mathrm{MnO}_{2}$ modified composites in absence and presence of RB5.

The degradation activity of the NGO-MnO nanocomposites was also investigated spectroscopically, by monitoring their decolorization efficiency with the UV-Vis spectra (250-750 nm) of the solution. Figure 12 presents the UV-vis spectra of the RB5 aqueous solutions after $2 \mathrm{~h}$ contact time with NGO- $\mathrm{MnO}_{2}$ and $\mathrm{NGO}-\mathrm{Mn}_{3} \mathrm{O}_{4}$ nanocomposites, at $\mathrm{pH}$ 3, for initial solutions of 5, 50 and $100 \mathrm{mg} / \mathrm{L}$ RB5. From the Figure, it is seen that for the pure RB5 solution, the maximum of absorbance was presented at $\lambda_{\max } \sim 593 \mathrm{~nm}$, in the visible region, that can be attributed to the $-\mathrm{N}=\mathrm{N}$ - azo bond of the dye [60]. The intensity of this peak is relative to the azo dye concentration in the solution and the blue color of the dye that is attributed to the $n \rightarrow p$ transition of the non-bonding electrons to the anti-banding pi-group orbital of the double bond system. Absorbances were also detected at $\lambda=230$ and $318 \mathrm{~nm}$ that are due to the benzene and naphthalene aromatic rings of RB5, respectively [61]. With the decrease of the initial concentration, the UV-vis spectra indicated a decrease of the band, due to the decolorization of the solution and the possible cleavage of the azo bonds for the formation of $-\mathrm{NH}_{2}$ groups [62], while after degradation different peaks were observed (Figure 13) at 238, 278 and $318 \mathrm{~nm}$ attributed to degradation products. 




Figure 12. UV-Vis curves for $\mathrm{RB} 5$ on $\mathrm{NGO}-\mathrm{Mn}_{3} \mathrm{O}_{4}$ in 3 different $\mathrm{RB} 5$ concentrations $(\mathrm{pH}=3, \mathrm{~m}=0.01 \mathrm{~g}$, $\mathrm{V}=0.02 \mathrm{~L})$.
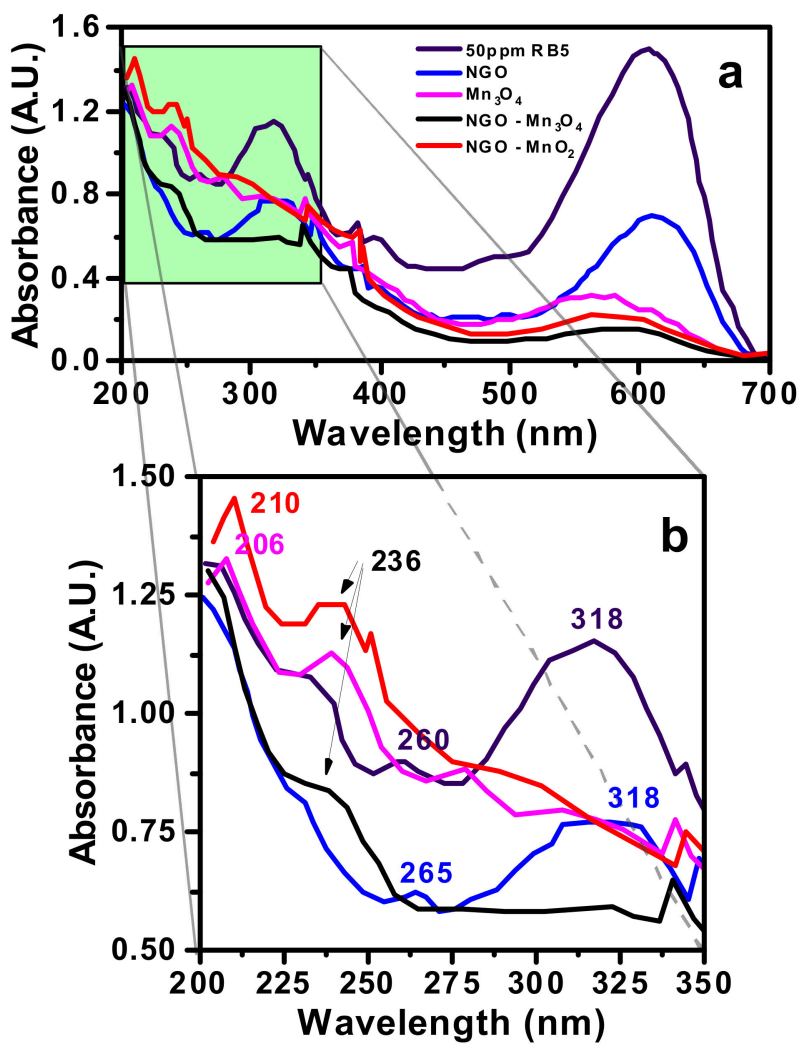

Figure 13. UV-Vis curves for RB5 (a,b) after degradation on $\mathrm{NGO}, \mathrm{MnO}_{2}, \mathrm{Mn}_{3} \mathrm{O}_{4}, \mathrm{NGO}-\mathrm{Mn}_{3} \mathrm{O}_{4}$ and NGO- $\mathrm{MnO}_{2}$ nanocomposites for $\mathrm{Co}=50 \mathrm{mg} / \mathrm{L}(\mathrm{pH}=3, \mathrm{~m}=0.01 \mathrm{~g}, \mathrm{~V}=0.02 \mathrm{~L}$ ).

Mechanism of RB5 Degradation

Recently, as concluded from the FTIR spectra based on the disappearance of the band at $1497 \mathrm{~cm}^{-1}$ indicative of the cleavage of the $-\mathrm{N}=\mathrm{N}$ - bond and the appearance of the band at $1640 \mathrm{~cm}^{-1}$ indicative of the presence of a primary amine as a result of RB5 degradation [38], the non-radical mechanism of RB5 degradation in an acidic environment could be described by the following equations [55]:

$$
\begin{gathered}
\mathrm{Mn} \rightarrow \mathrm{Mn}^{2+}+2 \mathrm{e}^{-} \\
2 \mathrm{H}_{2} \mathrm{O} \rightarrow \mathrm{H}_{3} \mathrm{O}^{+}+\mathrm{OH}^{-}
\end{gathered}
$$




$$
\begin{aligned}
2 \mathrm{H}_{3} \mathrm{O}^{+}+2 \mathrm{e}^{-} & \rightarrow \mathrm{H}_{2}+2 \mathrm{H}_{2} \mathrm{O} \\
\text { R-N=N-R }+\mathrm{H}_{2} & \rightarrow \text { R-NH-NH-R } \\
\text { R-NH-NH-R }+\mathrm{H}_{2} & \rightarrow \text { R-NH } \mathrm{NH}_{2}+\mathrm{R}_{-} \mathrm{NH}_{2}
\end{aligned}
$$

In acidic environment the favorable $\mathrm{H}_{3} \mathrm{O}^{+}$concentration increases and facilitate the degradation of RB5 by forming active $\mathrm{H}_{2}$ and therefore the cleavage of the $-\mathrm{N}=\mathrm{N}$ - bond of the azo-dye. The formation of hydrogen was testified by the appearance of bubbles in the solution during the redox reaction (inset photo in Figure 6). Hydroxyl groups are able to promote catalytic activity [37]. Besides, surface hydroxyl groups of the carbonaceous support facilitate the adsorption of RB5 through hydrogen bonds as well as the RB5 degradation through the intermediate oxidation. Modified graphene oxide, as manganese oxides' support, possesses a sufficient amount of hydroxylic groups due to the $\mathrm{NaOH}$ modification that leads to an increased RB5 degradation.

In the presence of $\mathrm{H}_{2} \mathrm{O}_{2}$ and therefore an $\mathrm{HO} \bullet$ radicals mechanism, the RB5 degradation increased for higher initial concentrations and decreased for lowered initial concentrations, may be due to a Fenton-like mechanism [63]. Mn ions react with $\mathrm{H}_{2} \mathrm{O}_{2}$ and hydroxyl radicals are produced that react and decompose the dye molecules according to the following Eqs. [63]:

$$
\begin{gathered}
\mathrm{Mn}(\mathrm{IV})+\mathrm{H}_{2} \mathrm{O}_{2} \rightarrow \mathrm{Mn}(\mathrm{IV}) \mathrm{H}_{2} \mathrm{O}_{2} \bullet \rightarrow \mathrm{Mn}(\mathrm{II})+\mathrm{HO}_{2} \bullet+\mathrm{H}^{+} \rightarrow 2 \mathrm{H}^{+}+\mathrm{O}_{2} \bullet \\
\mathrm{Mn}(\mathrm{II})+\mathrm{H}_{2} \mathrm{O}_{2} \rightarrow \mathrm{Mn}(\mathrm{IV})+\mathrm{HO} \bullet+\mathrm{OH}^{-} \\
\mathrm{HO} \bullet\left(\mathrm{O}_{2} \bullet-\text { dye } \rightarrow \mathrm{CO}_{2}+\mathrm{H}_{2} \mathrm{O}\right.
\end{gathered}
$$

As discussed above the mole ratio of RB5 initial concentration to $\mathrm{H}_{2} \mathrm{O}_{2}$ is a crucial and decisive parameter for the effect of the radicals on the RB5 degradation.

\section{Conclusions}

From the presented results, we can see the positive effect of the manganese oxide impregnation to sodium hydroxide modified graphene oxide on the efficiency of RB5 oxidative degradation. The efficiency was evaluated by kinetic results for the RB5 removal by $\mathrm{MnO}_{2}, \mathrm{Mn}_{3} \mathrm{O}_{4}$ and NGO-MnO 2 and NGO- $\mathrm{Mn}_{3} \mathrm{O}_{4}$ as well as by their chemical surface alterations after the removal process. From experimental as well as UV-vis and FTIR results, it is concluded that RB5 degradation is based on the release of $\mathrm{H}_{2}$, the cleavage of $-\mathrm{N}=\mathrm{N}$ - bonds and the formation of $-\mathrm{NH}_{2}$ groups. The presence of $\mathrm{H}_{2} \mathrm{O}_{2}$ could increase the RB5 degradation; $\mathrm{H}_{2} \mathrm{O}_{2}$ could produce hydroxyl radicals that are able to attack and decompose the dye molecules. Modified graphene oxide as manganese oxides' support possesses a sufficient amount of hydroxylic groups and leads to a more sufficient RB5 degradation.

Author Contributions: This article was written by E.D. after personal invitation for the Special Issue "Innovative Approaches for Drinking- and Waste-Water Treatment". H.S. contributed to the experimental design and experimental part, D.N. and K.R. contributed to experimental part.

Funding: This research received no external funding.

Conflicts of Interest: The authors declare no conflicts of interest.

\section{References}

1. Novotný, Č.; Dias, N.; Kapanen, A.; Malachová, K.; Vándrovcová, M.; Itävaara, M.; Lima, N. Comparative use of bacterial, algal and protozoan tests to study toxicity of azo-and anthraquinone dyes. Chemosphere 2006, 63, 1436-1442. [CrossRef]

2. Liang, J.; Ning, X.A.; Sun, J.; Song, J.; Lu, J.; Cai, H.; Hong, Y. Toxicity evaluation of textile dyeing effluent and its possible relationship with chemical oxygen demand. Ecotoxicol. Environ. Saf. 2018, 166, 56-62. [CrossRef] [PubMed] 
3. Bilal, M.; Iqbal, M.; Hu, H.; Zhang, X. Mutagenicity and cytotoxicity assessment of biodegraded textile effluent by Ca-alginate encapsulated manganese peroxidase. Biochem. Eng. J. 2016, 109, 153-161. [CrossRef]

4. Seralathan, J.; Salam, A.A.A.; Mohan, H.S.; Balaraman, D.; Pitchai, S.; Sadasivam, S.K. Evaluation of toxicity reduction in textile effluent by different treatment protocols involving marine diatom Odontella aurita on freshwater fish Labeo rohita. J. Water Process. Eng. 2017, 20, 232-242. [CrossRef]

5. Lademann, J.; Patzelt, A.; Worm, M.; Richter, H.; Sterry, W.; Meinke, M. Analysis of in vivo penetration of textile dyes causing allergic reactions. Laser Phys. Lett. 2009, 6, 759-763.

6. Rovira, J.; Domingo, J.L. Human health risks due to exposure to inorganic and organic chemicals from textiles: A review. Environ. Res. 2019, 168, 62-69. [CrossRef]

7. Hatch, K.L.; Maibach, H.I. Textile dye dermatitis. J. Am. Acad. Dermatol. 1995, 32, 631-639. [CrossRef]

8. Kiriakidou, F.; Kondarides, D.I.; Verykios, X.E. The effect of operational parameters and $\mathrm{TiO}_{2}$-doping on the photocatalytic degradation of azo-dyes. Catal. Today 1999, 54, 119-130. [CrossRef]

9. Pagga, U.; Brown, D. The degradation of dyestuffs: Part II. Behaviour of dyestuffs in aerobic biodegradation tests. Chemosphere 1986, 15, 479-491. [CrossRef]

10. Brown, D.; Laboureur, P. The aerobic biodegradability of primary aromatic amines. Chemosphere 1983, 12, 405-414. [CrossRef]

11. Ziarani, G.M.; Moradi, R.; Lashgari, N.; Kruger, H.G. Chapter 4-Azo Dyes; Ziarani, G.M., Moradi, R., Lashgari, N., Kruger, H.G.B.T.-M.-F.S.O.D., Eds.; Elsevier: Amsterdam, The Netherlands, 2018; pp. $47-93$.

12. Leme, D.M.; de Oliveira, G.A.R.; Meireles, G.; de Santos, T.C.; Zanoni, M.V.B.; de Oliveira, D.P. Genotoxicological assessment of two reactive dyes extracted from cotton fibres using artificial sweat. Toxicol. Vitr. 2014, 28, 31-38. [CrossRef]

13. Venturini, S.; Tamaro, M. Mutagenicity of anthraquinone and azo dyes in Ames' Salmonella typhimurium test. Mutat. Res. Toxicol. 1979, 68, 307-312. [CrossRef]

14. Akhtar, M.F.; Ashraf, M.; Anjum, A.A.; Javeed, A.; Sharif, A.; Saleem, A.; Akhtar, B. Textile industrial effluent induces mutagenicity and oxidative DNA damage and exploits oxidative stress biomarkers in rats. Environ. Toxicol. Pharmacol. 2016, 41, 180-186. [CrossRef]

15. Kabra, A.N.; Khandare, R.V.; Govindwar, P.S. Development of a bioreactor for remediation of textile effluent and dye mixture: A plant-bacterial synergistic strategy. Water Res. 2013, 47, 1035-1048. [CrossRef]

16. Bumpus, J.A. Microbial degradation of azo dyes. In Biotransformations; Singh, V.P.B.T.-P.i.I.M., Ed.; Elsevier: Amsterdam, The Netherlands, 1995; Volume 32, pp. 157-176.

17. Yang, P.; Shi, W.; Wang, H.; Liu, H. Screening of freshwater fungi for decolorizing multiple synthetic dyes. Braz. J. Microbiol. 2016, 47, 828-834. [CrossRef]

18. Jinqi, L.; Houtian, L. Degradation of azo dyes by algae. Environ. Pollut. 1992, 75, 273-278. [CrossRef]

19. Shu, H.-Y.; Chang, M.-C. Decolorization effects of six azo dyes by $\mathrm{O}_{3}, \mathrm{UV} / \mathrm{O}_{3}$ and $\mathrm{UV} / \mathrm{H}_{2} \mathrm{O}_{2}$ processes. Dye. Pigment. 2005, 65, 25-31. [CrossRef]

20. Fernandes, N.C.; Brito, L.B.; Costa, G.G.; Taveira, S.F.; Cunha-Filho, M.S.S.; Oliveira, G.A.R.; Marreto, R.N. Removal of azo dye using Fenton and Fenton-like processes: Evaluation of process factors by Box-Behnken design and ecotoxicity tests. Chem. Biol. Interact. 2018, 291, 47-54. [CrossRef]

21. Duarte, F.; Morais, V.; Maldonado-Hódar, F.J.; Madeira, L.M. Treatment of textile effluents by the heterogeneous Fenton process in a continuous packed-bed reactor using Fe/activated carbon as catalyst. Chem. Eng. J. 2013, 232, 34-41. [CrossRef]

22. Chun, H.; Yizhong, W. Decolorization and biodegradability of photocatalytic treated azo dyes and wool textile wastewater. Chemosphere 1999, 39, 2107-2115. [CrossRef]

23. Wang, H.-D.; Yang, Q.; Niu, C.H.; Badea, I. Adsorption of azo dye onto nanodiamond surface. Diam. Relat. Mater. 2012, 26, 1-6. [CrossRef]

24. Konicki, W.; Aleksandrzak, M.; Moszyński, D.; Mijowska, E. Adsorption of anionic azo-dyes from aqueous solutions onto graphene oxide: Equilibrium, kinetic and thermodynamic studies. J. Colloid Interface Sci. 2017, 496, 188-200. [CrossRef]

25. Hassan, M.M.; Carr, C.M. A critical review on recent advancements of the removal of reactive dyes from dyehouse effluent by ion-exchange adsorbents. Chemosphere 2018, 209, 201-219. [CrossRef]

26. Ouyang, J.; Zhao, Z.; Suib, S.L.; Yang, H. Degradation of Congo Red dye by a $\mathrm{Fe}_{2} \mathrm{O}_{3} @ \mathrm{CeO}_{2}-\mathrm{ZrO}_{2} /$ Palygorskite composite catalyst: Synergetic effects of $\mathrm{Fe}_{2} \mathrm{O}_{3}$. J. Colloid Interface Sci. 2019, 539, 135-145. [CrossRef] 
27. Natarajan, S.; Bajaj, H.C.; Tayade, R.J. Recent advances based on the synergetic effect of adsorption for removal of dyes from waste water using photocatalytic process. J. Environ. Sci. 2018, 65, 201-222. [CrossRef]

28. Rong, X.; Qiu, F.; Zhang, C.; Fu, L.; Wang, Y.; Yang, D. Adsorption-photodegradation synergetic removal of methylene blue from aqueous solution by NiO/graphene oxide nanocomposite. Powder Technol. 2015, 275, 322-328. [CrossRef]

29. Nagpal, M.; Kakkar, R. Use of metal oxides for the adsorptive removal of toxic organic pollutants. Sep. Purif. Technol. 2019, 211, 522-539. [CrossRef]

30. Islam, M.A.; Morton, D.W.; Johnson, B.B.; Mainali, B.; Angove, M.J. Manganese oxides and their application to metal ion and contaminant removal from wastewater. J. Water Process. Eng. 2018, 26, 264-280. [CrossRef]

31. Salam, M.A. Synthesis and characterization of novel manganese oxide nanocorals and their application for the removal of methylene blue from aqueous solution. Chem. Eng. J. 2015, 270, 50-57. [CrossRef]

32. Peng, H.H.; Chen, J.; Jiang, D.Y.; Li, M.; Feng, L.; Losic, D.; Zhang, Y.X. Synergistic effect of manganese dioxide and diatomite for fast decolorization and high removal capacity of methyl orange. J. Colloid Interface Sci. 2016, 484, 1-9. [CrossRef]

33. Dang, T.-D.; Banerjee, A.N.; Tran, Q.-T.; Roy, S. Fast degradation of dyes in water using manganese-oxide-coated diatomite for environmental remediation. J. Phys. Chem. Solids 2016, 98, 50-58. [CrossRef]

34. Saroyan, H.S.; Giannakoudakis, D.A.; Sarafidis, C.S.; Lazaridis, N.K.; Deliyanni, E.A. Effective impregnation for the preparation of magnetic mesoporous carbon: Application to dye adsorption. J. Chem. Technol. Biotechnol. 2017, 92, 1899-1911. [CrossRef]

35. Gupta, K.; Khatri, O.P. Reduced graphene oxide as an effective adsorbent for removal of malachite green dye: Plausible adsorption pathways. J. Colloid Interface Sci. 2017, 501, 11-21. [CrossRef]

36. Minitha, C.R.; Lalitha, M.; Jeyachandran, Y.L.; Senthilkumar, L. Adsorption behaviour of reduced graphene oxide towards cationic and anionic dyes: Co-action of electrostatic and $\pi-\pi$ interactions. Mater. Chem. Phys. 2017, 194, 243-252.

37. Saroyan, H.S.; Arampatzidou, A.; Voutsa, D.; Lazaridis, N.K.; Deliyanni, E.A. Activated carbon supported $\mathrm{MnO}_{2}$ for catalytic degradation of reactive black 5. Colloids Surf. A Physicochem. Eng. Asp. 2019, 566, 166-175. [CrossRef]

38. Saroyan, H.; Kyzas, Z.G.; Deliyanni, A.E. Effective Dye Degradation by Graphene Oxide Supported Manganese Oxide. Processes 2019, 7, 40. [CrossRef]

39. Saroyan, H.S.; Bele, S.; Giannakoudakis, D.A.; Samanidou, V.F.; Bandosz, T.J.; Deliyanni, E.A. Degradation of endocrine disruptor, bisphenol-A, on an mixed oxidation state manganese oxide/modified graphite oxide composite: A role of carbonaceous phase. J. Colloid Interface Sci. 2019, 539, 516-524. [CrossRef]

40. Saroyan, H.; Ntagiou, D.; Samanidou, V.; Deliyanni, E. Modified graphene oxide as manganese oxide support for bisphenol A degradation. Chemosphere 2019, 225, 524-534. [CrossRef]

41. Hummers, W.S.; Offeman, R.E. Preparation of Graphitic Oxide. J. Am. Chem. Soc. 1958, 80, 1339. [CrossRef]

42. Yang, Z.; Zhang, Y.; Zhang, W.; Wang, X.; Qian, Y.; Wen, X.; Yang, S. Nanorods of manganese oxides: Synthesis, characterization and catalytic application. J. Solid State Chem. 2006, 179, 679-684. [CrossRef]

43. Cao, D.; Li, H.; Wang, Z.; Wei, J.; Wang, J.; Liu, Q. Synthesis, nanostructure and magnetic properties of FeCo-reduced graphene oxide composite films by one-step electrodeposition. Thin Solid Films 2015, 597, 1-6. [CrossRef]

44. Xu, R.; Wang, X.; Wang, D.; Zhou, K.; Li, Y. Surface structure effects in nanocrystal $\mathrm{MnO}_{2}$ and $\mathrm{Ag} / \mathrm{MnO}_{2}$ catalytic oxidation of CO. J. Catal. 2006, 237, 426-430. [CrossRef]

45. Ren, Y.; Yan, N.; Wen, Q.; Fan, Z.; Wei, T.; Zhang, M.; Ma, J. Graphene/ $\delta-\mathrm{MnO}_{2}$ composite as adsorbent for the removal of nickel ions from wastewater. Chem. Eng. J. 2011, 175, 1-7. [CrossRef]

46. Patterson, A.L. The Scherrer Formula for X-Ray Particle Size Determination. Phys. Rev. 1939, 56, 978-982. [CrossRef]

47. Laffont, L.; Gibot, P. High resolution electron energy loss spectroscopy of manganese oxides: Application to $\mathrm{Mn}_{3} \mathrm{O}_{4}$ nanoparticles. Mater. Charact. 2010, 61, 1268-1273. [CrossRef]

48. Lee, C.H.; Lee, S.; Yeo, J.S.; Kang, G.S.; Noh, Y.J.; Park, S.M.; Lee, D.C.; Na, S.I.; Joh, H.I. Hybrid materials of upcycled $\mathrm{Mn}_{3} \mathrm{O}_{4}$ and reduced graphene oxide for a buffer layer in organic solar cells. J. Ind. Eng. Chem. 2018, 61, 106-111. [CrossRef] 
49. Yang, Y.J. One-pot synthesis of reduced graphene oxide/zinc sulfide nanocomposite at room temperature for simultaneous determination of ascorbic acid, dopamine and uric acid. Sens. Actuators B Chem. 2015, 221, 750-759. [CrossRef]

50. Xu, Y.; Bai, H.; Lu, G.; Li, C.; Shi, G. Flexible Graphene Films via the Filtration of Water-Soluble Noncovalent Functionalized Graphene Sheets. J. Am. Chem. Soc. 2008, 130, 5856-5857. [CrossRef] [PubMed]

51. Duan, X.; Sun, H.; Ao, Z.; Zhou, L.; Wang, G.; Wang, S. Unveiling the active sites of graphene-catalyzed peroxymonosulfate activation. Carbon 2016, 107, 371-378. [CrossRef]

52. Xu, L.; Xu, C.; Zhao, M.; Qiu, Y.; Sheng, G.D. Oxidative removal of aqueous steroid estrogens by manganese oxides. Water Res. 2008, 42, 5038-5044. [CrossRef]

53. Khaled, A.; Nemr, A.E.; El-Sikaily, A.; Abdelwahab, O. Removal of Direct N Blue-106 from artificial textile dye effluent using activated carbon from orange peel: Adsorption isotherm and kinetic studies. J. Hazard. Mater. 2009, 165, 100-110. [CrossRef]

54. Pfaffeneder-Kmen, M.; Casas, I.F.; Naghilou, A.; Trettenhahn, G.; Kautek, W. A Multivariate curve resolution evaluation of an in-situ ATR-FTIR spectroscopy investigation of the electrochemical reduction of graphene oxide. Electrochim. Acta 2017, 255, 160-167. [CrossRef]

55. Mbarek, W.B.; Azabou, M.; Pineda, E.; Fiol, N.; Escoda, L.; Suñol, J.J.; Khitouni, M. Rapid degradation of azo-dye using Mn-Al powders produced by ball-milling. RSC Adv. 2017, 7, 12620-12628. [CrossRef]

56. Méndez-Martínez, A.J.; Dávila-Jiménez, M.M.; Ornelas-Dávila, O.; Elizalde-González, M.P.; Arroyo-Abad, U.; Sirés, I.; Brillas, E. Electrochemical reduction and oxidation pathways for Reactive Black 5 dye using nickel electrodes in divided and undivided cells. Electrochim. Acta 2012, 59, 140-149. [CrossRef]

57. Feng, Q.; Kanoh, H.; Miyai, Y.; Ooi, K. Metal ion extraction/insertion reactions with todorokite-type manganese oxide in the aqueous phase. Chem. Mater. 1995, 7, 1722-1727. [CrossRef]

58. Kapteijn, F.; Singoredjo, L.; Andreini, A.; Moulijn, J.A. Activity and selectivity of pure manganese oxides in the selective catalytic reduction of nitric oxide with ammonia. Appl. Catal. B Environ. 1994, 3, 173-189. [CrossRef]

59. Singu, B.S.; Yoon, K.R. Exfoliated graphene-manganese oxide nanocomposite electrode materials for supercapacitor. J. Alloys Compd. 2019, 770, 1189-1199. [CrossRef]

60. Ferreira, L.C.; Lucas, M.S.; Fernandes, J.R.; Tavares, P.B. Photocatalytic oxidation of Reactive Black 5 with UV-A LEDs. J. Environ. Chem. Eng. 2016, 4, 109-114. [CrossRef]

61. Santos, P.B.; Santos, J.J.; Corrêa, C.C.; Corio, P.; Andrade, G.F.S. Plasmonic photodegradation of textile dye Reactive Black 5 under visible light: A vibrational and electronic study. J. Photochem. Photobiol. A Chem. 2019, 371, 159-165. [CrossRef]

62. Wanyonyi, W.C.; Onyari, J.M.; Shiundu, P.M.; Mulaa, F.J. Effective biotransformation of Reactive Black 5 Dye Using Crude Protease from Bacillus Cereus Strain KM201428. Energy Procedia 2019, 157, 815-824. [CrossRef]

63. Ramesh, M.; Nagaraja, H.S.; Rao, M.P.; Anandan, S.; Huang, N.M. Fabrication, characterization and catalytic activity of $\alpha-\mathrm{MnO}_{2}$ nanowires for dye degradation of reactive black 5. Mater. Lett. 2016, 172, 85-89. [CrossRef]

(C) 2019 by the authors. Licensee MDPI, Basel, Switzerland. This article is an open access article distributed under the terms and conditions of the Creative Commons Attribution (CC BY) license (http://creativecommons.org/licenses/by/4.0/). 